DOI: $10.31249 / \mathrm{rsm} / 2020.04 .02$

\title{
E.E. Савицкий
}

\section{БЫАИ АИ КОАОНИААЬНЫЕ ГОСТИНИЦЫ ФОРПОСТАМИ ЕВРОПЕЙСКОЙ КУАЬТУРЫ? СВИАЕТЕАЬСТВА РУССКИХ ПУТЕШЕСТВЕННИКОВ ПО НИАЕРААНАСКОЙ ИНАИИ КОНЦА ХIX - НАЧААА XX В. *}

Аннотация. Цель исследования - анализ концепции М. Пелегги, указывавщего на важную роль быстро развивавшейся в Южной и Восточной Азии после строительства Суэикого канала туристической инфраструктуры, особенно гостинии, для распространения современного европейского образа жизни, утверждения престижа имперской власти среди туземцев. В качестве источников используются записки русских путешественников, побывавших в конце XIX-начале XX в. в Нидерландской Индии, на о. Ява. Автор показал, что гостиницы в Батавии и Бейтензорге нельзя отнести к форпостам европейской культуры или колониальным «зонам комфорта». Все путешественники испьтывали существенные неудобства, отношение к обстановке яванских гостиниц варьировалось от возмущения до снисходительности. Лишь одна гостиница из рассмотренных четырех предлагала европейскую кухню, ни в одной не было заслуживающих упоминания европейских развлечений. Посетители гостинии ощущают свою европейскую идентичность не потому, что чувствуют себя там как дома, а наоборот, поскольку противопоставляют свой культурный опьт гостиничным условиям жизни. В то же время наблюдение за гостиничной жизнью позволяет некоторым гостям делать замечания, допускающие бо́льшую, чем принято в России, телесную свободу, рачиональность одежды, отказ от некоторых приличий. В источниках, однако, нет упоминаний о сексуальном или каком-то ином трансгрессивном опыте, связанном с гостиницами. Гостиницы не выступают и местом нарушения сочиальных или этнических границ. В целом, однако, гостиниць действительно оказываются культурно значимыми колониальными институциями, о которых более или менее подробно пишут все путешественники.

Ключевые слова: колониальная гостиница; Нидерландская Индия; Ява; Батавия; Бейтензорг; русские путешественники; имперские идентичности.

* Исследование выполнено за счет гранта Российского научного фонда (проект № 20-18-00482). 


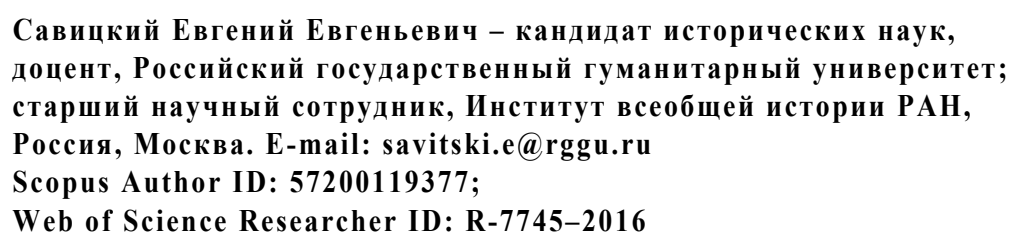

Savitskiy E.E. Were Colonial Hotels the Outposts of European Culture? Testimonies of Russian Travelers to Netherlands Indies from Late Nineteenth and Early Twentieth Centuries

Abstract. The article aims at testing the concept of M. Peleggi, who pointed at the important role of the tourism infrastructure, which rapidly developed in South and East Asia after the construction of the Suez Canal, especially hotels, for the spread of the modern European way of life and asserting the prestige of imperial power among the natives. The sources used are the notes of Russian travelers who visited the island of Java in the Netherlands Indies in the late nineteenth - early twentieth century. The analysis proves that the hotels in Batavia and Beitenzorg cannot be classified as outposts of European culture or colonial "comfort zones». All travelers experienced considerable inconveniences, and attitudes towards the furnishings of Javanese hotels ranged from indignation to condescension. Only one hotel out of the four under review offered European cuisine, while none of them had any European entertainment worth mentioning. Hotel visitors experienced their European identity not because they felt at home there, but, on the contrary, because they contrasted their cultural experience with the hotel living conditions. At the same time, observing the hotel life allowed some guests making remarks about greater bodily freedom than is customary in Russia, the rationality of clothing, and the rejection of certain proprieties. The sources, however, do not mention any sexual or any other transgressive hotel-related experience. Hotels did not stand out as a place for violation of social or ethnic boundaries. In general, however, as all travelers described in more or less detail, they did not prove to be culturally significant colonial institutions.

Keywords: colonial hotel; Netherlands Indies; Java; Batavia; Beitenzorg; Russian travelers; imperial identities.

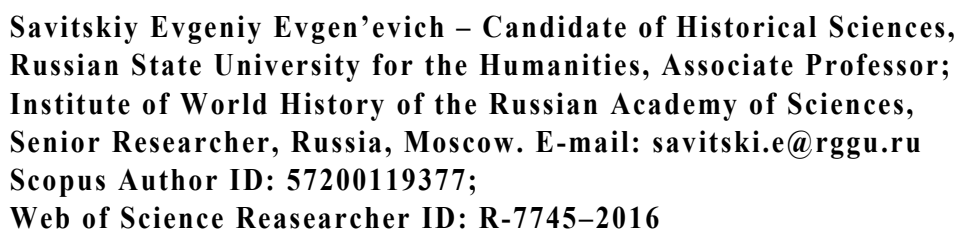

В статье «Социальная и материальная жизнь колониальных гостиниц» итальянский исследователь Маурицио Пелегги [Peleggi 2012] пишет, что в период с 1870 по 1930 г., от открытия Суэцкого канала до Великой депрессии, по-европейски устроенные гостиницы стали в колониальных городах 
важнейшими точками притяжения. Эпоха «высокого империализма» обеспечивала европейским путешественникам, направлявшимся в Азию, политическую стабильность, материальную инфраструктуру, ощущение собственной безопасности и уверенности в себе. На примере Коломбо и Сингапура, двух крупных транзитных портов в Индийском океане, Пелегги показывает, что новые гостиницы предлагали более высокий, чем раньше, уровень комфорта, их посетители могли наслаждаться тем же образом жизни, что и в метрополии. Это касалось как архитектуры зданий, так и их технического оснащения, гастрономии и программы развлечений. Тем самым гостиницы оказывались важным инструментом перенесения в колонии элементов современного европейского образа жизни. Кроме того, как микрокосмы колониального общества гостиницы воплощали собой социальные различия между европейцами, уверенными в своем культурном превосходстве, и местными жителями, которые подлежали воспитанию в соответствии с более высокими цивилизационными стандартами. Гостиницы, считает Пелегги, были также местами, в роскоши которых особенно наглядно проявлялось накопление капиталов, осуществлявшееся путем эксплуатации местных жителей. При этом колониальные гостиницы были для европейцев не только зонами комфорта, но и контактными зонами, где взаимодействовали различные социальные, этнические и религиозные группы. Их изучение, по мнению Пелегги, требует обращать внимание не только на имевшиеся у колониальных элит привычки потребления, но также и на глобальное циркулирование престижных продуктов и социокультурных практик обращения с ними, а также на ежедневные взаимодействия между колонизаторами и колонизируемыми, между различными стратами колониального общества.

Как отмечает Пелегги, сложность изучения колониальных гостиниц связана с плохой сохранностью архивов частных коммерческих фирм, которым эти гостиницы принадлежали, поэтому особое значение имеют записки путешественников, позволяющие реконструировать повседневную жизнь гостиниц. В этой статье будут рассмотрены записки русских путешественников, направлявшихся в Нидерландскую Индию (совр. Индонезию), которая во многих отношениях отличалась от британских владений в этом регионе. Из-за языкового барьера эти записки русских путешественников практически не используются европейскими и американскими исследователями, между тем в них встречаются порой довольно подробные рассказы о гостиничной жизни, способные дополнить или скорректировать данные, полученные Пелегги. Своеобразие записок русских путешественников в том, что они находили в равной мере удивительными и заслуживающими описания как быт туземцев, так и колониальный образ жизни европейцев. В 1891 г. о. Ява, центр нидерландских колониальных владений, посетили великие князья Александр и Сергей Михайловичи. О своих впечатлениях они сообщали в письмах друзьям 
по «Картофельной компании» (в нее входили, кроме двух Михайловичей, цесаревич Николай Александрович, его брат Георгий, сестра Ксения, двое сыновей и четыре дочери министра двора графа И.И. Воронцова-Дашкова и еще несколько человек; письма в поездке писал в основном Александр Михайлович). Великих князей сопровождал географ и натуралист Густав Иванович Радде, составивший на немецком языке записки об этом путешествии, опубликованные уже в 1892 г. в русском переводе. Радде больше известен своими исследованиями Кавказа, как раз там он познакомился с отцом Александра и Сергея Михайловичей, великим князем Михаилом Николаевичем, занимавшим в 1862-1881 гг. должность наместника на Кавказе. В итоге именно Радде было предложено сопровождать молодых великих князей в плавании на яхте «Тамара», которое включало посещение также ряда других восточных стран. В 1893 г. Яву посетил князь Александр Григорьевич Щербатов с супругой Ольгой Александровной, написавшей впоследствии книгу «В стране вулканов: путевые заметки на Яве». Год спустя на Яву прибывает российский дипломат Модест Модестович Бакунин, который был первым и последним консулом в Нидерландской Индии русского происхождения, до этого и позднее они назначались из числа местных голландцев. Бакунин также описал свою жизнь на Яве в записках, которые по возвращении на родину издал в виде книги «Тропическая Голландия. Пять лет на острове Ява» (1902). Особую группу путешественников составляли российские натуралисты, которых привлекал ботанический сад в Бейтензорге. В 1892 г. Яву посетил Андрей Николаевич Краснов, ботаник и географ, профессор Харьковского университета, старший брат известного впоследствии казачьего офицера и писателя П.Н. Краснова. Путешествие Краснова, включавшее в себя также посещение Японии, Китая, Индии и Цейлона, описано в его книге «По островам далекого Востока» (1895). В 1909 г. Яву посетил другой профессор Харьковского университета, Владимир Митрофанович Арнольди, также написавший о своем путешествии книгу. Таким образом, имеющиеся свидетельства принадлежат людям разного социального статуса: представителям высшего света, чиновнику, представителям академической среды.

Все путешественники, сойдя на берег в порту Танджунг-Приок, направляются сначала в Батавию (совр. Джакарта), столицу Нидерландской Индии. Великие князья ночуют здесь в доме российского консула, поэтому о гостинице ничего не рассказывают. Щербатовых уже на пристани встречает «посланный» из «Отель дер Недерланден», от вокзала в экипаже они едут прямо в гостиницу. Как пишет О.А. Щербатова, все гостиницы на Яве строятся по одному плану, и «Отель дер Недерланден» не был исключением: в центре располагался обширный двор, обсаженный деревьями и окруженный с четырех сторон зданиями, «в переднем из них находилась гостиная с дверьми, выходящими на широкий крытый балкон, вымощенный мраморными плитами 
с расставленными по нему столами, креслами и стульями. Вечером балкон ярко освещался и был любимым местом пребывания живущих в гостинице в до- и послеобеденное время» [Щербатова 2009, с. 99]. Сзади к гостиной примыкала столовая, открытая со всех сторон и выступавшая во двор. Она была украшена различными растениями, наполнявшими боковые арки. «В этом же главном здании помещались лучшие спальни, и, между прочим, наши, отличавшиеся от прочих большей вышиной и комфортом» [Щербатова 2009, с. 99]. Остальные три стороны двора были окружены верандой, «служившей гостиной для спален и выходивших на нее дверьми. Перегороженная местами ширмами и уставленная мебелью, веранда затенялась спереди от солнца большими спускавшимися соломенными жалузиями, заслонявшими также сидящих от взоров прохожих» [Щербатова 2009, с. 99]. Таким образом, гостиница имеет вполне ясную структуру, а также подчеркивает социальные различия между останавливающимися в ней. «Отель дер Недерланден» был основан еще в конце XVIII в. и сохранял, несмотря на позднейшие перестройки, свой классицистически ясный облик. Как и другие путешественники, Щербатова отмечает, что в Батавии вообще преобладали белые здания с колоннами в греческом стиле: «Дома с широкими портиками ослепительной белизны, ионическими колоннами и мраморными полами выглядывают из своей оправы зеленых деревьев» [Щербатова 2009, с. 102]. Голландский город на Яве оказывался подобием греческой колонии античных времен, и его жители должны были воплощать собой соответствующие, унаследованные от греков, ценности. Эти античные аллюзии в облике отеля Щербатова, однако, в дальнейшем никак не акцентирует.

В окружающих корпуса гостиницы верандах Щербатова видит большое удобство - можно «проводить время на открытом воздухе вместо того, чтобы запираться в удушливых комнатах» [Щербатова 2009, с. 100]. Комнаты, таким образом, проветриваются плохо, но и у пребывания на веранде есть недостатки - путешественник делается открытым для всеобщего обозрения: «Нельзя выйти во двор, не подвергаясь любопытным взорам многочисленных зрителей» [Щербатова 2009, с. 100]. Еще одним неудобством оказалось то, что «ванные комнаты помещались в самом конце двора», и на следующее утро княгине «пришлось идти туда в утреннем костюме мимо веранд, где уже сидели многие жители гостиницы, пьющие утренний чай» [Щербатова 2009, c. 104]. Ванные комнаты были «подобно пароходным, не имеющими ванн», в них «на каменном полу поставлена решетчатая доска, а рядом с ней огромный бак с водою, с небольшим лишь отверстием, вероятно из предосторожности, чтобы кто-нибудь по ошибке не выкупался бы в нем. Способ купанья обливаньем холодной водой отчасти освежает больше, чем окунание, но зато он медлен и скучен» [Щербатова 2009, с. 104]. Таким образом, Щербатова 
отнюдь не находит в «Отель дер Недерланден» того комфорта, которого можно было бы ожидать от европейской гостиницы.

Возвращаясь после купания, княгиня «застала уже всех мужчин на своих верандах с голыми ногами, перекинутыми через ручки кресел» [Щербатова 2009 , с. 104]. Это зрелище также не доставляет путешественнице удовольствия, она, однако, комментирует его цитатой из записок некой английской путешественницы, чье имя не называет: «Эта публичность домашней жизни является последствием климатических условий. Удобные позы и костюмы negligé понятны у себя дома, но не в публичной гостинице, а между тем понемногу привыкаешь к ним и находишь их вполне естественными в столь жарком климате» [Щербатова 2009, с. 104]. Схожим образом Щербатова оправдывает и вообще довольно свободную манеру голландцев одеваться: «Для непривычного глаза подобная манера одеваться кажется не только странной, но даже и неприличной, а между тем голландцы поступают в гигиеническом отношении весьма разумно, согласуя свое одеяние с климатическими условиями, в которых им приходится жить; тем более, что такие кажущиеся мелочи, как форма одежды, имеют очень значительное влияние на здоровье, и наше европейское платье вовсе неподходяще к тропическим жарам» [Щербатова 2009, с. 105]. Таким образом, поначалу воспринимаемое в качестве неприличного поведение голландцев на веранде гостиницы в итоге оказывается вполне разумным, обосновываемым соображениями гигиены. Щербатова использует даже аргументы вроде тех, какими пользовались в те годы сторонники движения за реформу женской одежды: платье не должно оказывать негативное влияние на здоровье. Можно сказать, что для княгини гостиница действительно оказывается в каком-то смысле проводником современных нравов, как о ней писал Пелегги. В гостинице происходит знакомство с иным культурным опытом, более свободными формами поведения, новым пониманием комфорта. Прежние стереотипы относительно приличного / неприличного преодолеваются в пользу разумного и здорового.

Что касается общения с другими постояльцами гостиницы, то оно оказывается весьма ограниченным, и, по-видимому, не столько из-за высокого статуса путешественников, сколько из-за языкового барьера. По словам Щербатовой, в Батавии «всюду, где мы побывали, все говорили только поголландски и весьма немногие - на ломаном французском языке». Князь Щербатов, «мечтавший, что, зная немецкий язык, ему легко будет изьясняться здесь, решительно ничего не понимал из сказанного ему» [Щербатова 2009, c. 100]. Во время утреннего чая супругов навещает российский консул, голландец Бауд, хорошо говоривший по-французски, он рассказывает о страшном извержении вулкана Кракатау в 1883 г. Перед отъездом из гостиницы супругов удивил сильно завышенный, по их мнению, счет, так что они даже 
сообщили владельцу о своем намерении больше никогда тут не останавливаться.

И действительно, когда на обратном пути Щербатовы снова приедут в Батавию, они остановятся в «Гранд отель де Жава», «гостинице во всех отношениях прекрасной: хорошие комнаты, весьма услужливый, любезный хозяин и главное, благодаря повару-французу, - отличный стол» [Щербатова 2009, с. 229]. Щербатовы были рады, наконец, найти европейскую кухню, которую не предлагали в других гостиницах. Большую часть времени путешественники снова проводят на веранде, при этом появляется новое неудобство, которое княгиня, однако, превращает в преимущество: «С утра до поздней ночи около веранды наших комнат толпились продавцы-китайцы, предлагавшие разный товар. Я воспользовалась тем, что они провели у нас, так сказать, весь день, чтобы не спеша выторговать многие вещи очень дешево, начав торговаться вскоре после приезда и покончив свои покупки под вечер» [Щербатова 2009, с. 229]. К этому времени Щербатова уже немного выучила малайский язык и могла отвечать китайцам: «Так как я сидела с книгой в руках на балконе, а китайцы тут же рядом на ступеньках, то целый почти день можно было бы услышать следующего рода диалог: “Мем сахиб," - начинал заискивающим голосом торговец, показывая вазу, - "инисаамат бай паасубунгу", “это очень красивая ваза". Я, не подымая глаз с книги и делая вид, что нисколько не желаю купить предлагаемую вещь: “Брагпаахаргааини?”, “Какая цена?” Тот назначает, конечно, баснословно дорогую цену. Я: “Тилампоумах-хал”, “Слишком дорого”» [Щербатова 2009, с. 229-230]. В итоге этот разговор повторялся, пока Щербатова и китаец не сходились в цене. Можно сказать вслед за Пелегги, что гостиница здесь оказывается не только местом межкультурной коммуникации, но и воплощением социальных различий: китаец сидит под балконом и заискивающе обращается к белой госпоже, которая время от времени говорит ему «Пигги, пигги!» - «Убирайся!» [Щербатова 2009, с. 230]. Впрочем, в описании русской путешественницы дело выглядит так, как будто обе стороны воспринимали это общение просто как хитрую игру, и для читателя она представлялась элементом экзотической повседневности.

В этом же «Гранд отель де Жава» останавливался годом ранее А.Н. Краснов. Это жилье ему порекомендовали уже на борту парохода, и в порту его ожидал специальный гостиничный омнибус, что было для путешественника большим облегчением, так как, не владея малайским, он боялся искать нужный адрес самостоятельно [Краснов 1895, с. 272]. Краснов обращает внимание своих читателей на то, что, в отличие от англичан, всячески поощряющих своих подданных к изучению английского языка, голландцы, наоборот, препятствуют изучению голландского, язык сохраняется как средство отличия белых людей. Путешественник выбирает «Гранд отель де Жава» главным 
образом потому, что гостиница - французская, т.е. в ней не должно было возникнуть языковых трудностей. Впрочем, позднее Краснов отмечает, что все местные голландцы, вопреки свидетельству Щербатовой, хорошо говорят или по-французски, или по-немецки, у него не возникало проблем в коммуникации с ними. Главной целью Краснова был, как уже говорилось, Бейтензорг с его ботаническим садом, поэтому он не задерживается в Батавии и не сообщает других подробностей о пребывании в здешней гостинице. В 1909 г. профессор Арнольди и вовсе проедет поездом прямо в Бейтензорг, не останавливаясь в Батавии.

Вообще в столице Нидерландской Индии было в это время три крупных отеля, где останавливались европейцы. Кроме упоминавшихся уже «Отель дер Недерланден» и «Гранд отель де Жава» был еще «Отель дез Анд», который Пелегги относит к наиболее знаменитым в ту эпоху, ставя его в один ряд с «Континенталем» в Сайгоне и «Метрополем» в Ханое. Именно в «Отель дез Анд» сразу по прибытии останавливается М.М. Бакунин, назначенный консулом вместо Бауда. Гостиница произвела на российского чиновника весьма скверное впечатление, он ставит ее ниже петербургского Гостиного двора. Впрочем, Бакунин вообще гораздо критичней других авторов отзывается о жизни в Нидерландской Индии [Савицкий 2019]. Как он пишет, ему «приходилось существовать более или менее скверно, и скорее более, чем менее, в караван-сарае, пещере, трактире третьего разбора, что угодно, только никак не в гостинице, именуемой Hotel des Indes и имеющей ничем не оправдываемую претензию считаться первым отелем в Батавии. [...] Кратковременное, к счастью, пребывание мое в этой перворазрядной разбойничьей пещере составляет незабвенную и весьма печальную страничку моего дебюта в Индии и заслуживает описания для примера и острастки других туристов, которых судьба-мачеха занесет в эту негостеприимную страну обезьян и малярии» [Бакунин 2007, с. 43].

Причины для недовольства у Бакунина во многом те же, что у Щербатовой в «Отель дер Недерланден»: цена проживания, несоизмеримая с качеством предоставляемых услуг («Комфорту никакого, прислуги не дозовешься, кормление отвратительное, дороговизна, даже прямо эксплуатация, возмутительная, и притом непостижимо, на что уходит уйма денег...» [Бакунин 2007, c. 44]), и несоблюдение другими постояльцами элементарных приличий. Причем, если Щербатова обращает внимание на сидящих с голыми ногами мужчин, то у Бакунина вызывает отвращение вид женских ног: «К завтраку дамы являются в своем неприличном sarong'е и в кабайе (кофте) с босыми ногами. Эти ряды грязных голых пяток и шлепающих туфель под столом, впрочем, вполне гармонируют с тою неопрятною снедью, которая подается на стол - одно к одному» [Бакунин 2007, с. 44]. 
Надо сказать, что на утренний женский костюм обращает в Батавии внимание и великий князь Александр Михайлович: «Утренний костюм европеек весьма оригинален, они носят малайскую юбку, туфли на босые ноги и легкую полотняную курточку, костюм весьма практичный для здешнего климата и вместе с тем красивый». Великий князь упоминает, что такой наряд вызывает возмущение у англичанок, которые находят его шокирующим и предпочитают даже в самую сильную жару носить европейское платье с корсетом, но, по мнению Александра Михайловича, голландские женщины «молодцы, что не стесняются» [Письма 2017, 99].

Говоря о еде, Щербатова упоминала лишь, что была рада найти, наконец, в «Гранд отель де Жава» французскую кухню. В «Отель дез Анд» ее не было, и Бакунин подробно описывает те отвратительные местные кушанья, что там подвались: «Кормят в отеле четыре раза в день в изобилии, но из рук вон плохо. [...] Встаешь из-за стола голодный, а впереди - завтра, послезавтра, постоянно имеется в виду все то же отвратительное питание» [Бакунин 2007, c. 46,48$]$. Впрочем, утренний кофе с закусками, о котором упоминает и Щербатова, оказывается приемлемым, Бакунин пишет лишь о необычности его приготовления. По-настоящему отвратительным представляется ему подаваемый в час дня ко второму завтраку «Reistafel» (рисовый стол). Поскольку рис варится не в воде, а на пару, он оказывается «похожим на жеваную бумагу» [Бакунин 2007, с. 47]. Рис поливается «мутно-желтой похлебкой с кэрри» [Бакунин 2007, с. 47], в него предлагается также добавлять приправы, после которых «ваше нёбо и вся внутренность мгновенно начинают гореть, как в огне» [Бакунин 2007, с. 47]. Затем в рис валят без разбору кур в разных видах, лепешки из рыбы, жареные бананы и проч., и такое смешение всего на свете представляется Бакунину верхом безвкусия. Вечером в половине девятого подают бифштекс с жареным картофелем. Все это повторяется изо дня в день без какого-либо разнообразия.

Отвращение вызывают также ящерицы и насекомые, которыми кишит гостиница. Открыв у себя в комнате «полуразвалившийся» шкаф, Бакунин увидел, как в нем «весело и нахально прыгали жирные и вонючие коричневые тараканы и взапуски гонялись за мошками и комарами проворные серозеленые ящерицы» [Бакунин 2007, с. 44]. Чуть дальше он пишет, что вообще по стенам и потолку комнаты сновали ящерицы, муравьи и тараканы. В отличие от Щербатовых, выбравших особенно просторный номер, Бакунин жил в «душной каморке, меблированной самым примитивным образом» [Бакунин 2007 , с. 44]. Примечательно, что автор лишь мельком упоминает о верандах, на которых, по словам Щербатовой, было принято проводить основную часть времени, пребывание в гостинице означает для него именно нахождение в комнате. Сидеть на веранде, свесив на виду у всех голые ноги, Бакунин находил для себя неприемлемым. В комнате кроме шкафа была огромная 
кровать под кисейным пологом для защиты от комаров, умывальный стол, ширма, столик, два кресла, а также широкая качалка, в которой, по словам Бакунина, «голландцы проводят, среди тупого созерцания своих необутых ног, три четверти своего существования» [Бакунин 2007, с. 44]. В целом «Отель дез Анд» выглядит примерно так же, как и «Отель дер Недерланден». В отличие от внутренней обстановки, неоклассический внешний вид гостиницы Бакунин находит даже «симпатичным»: «Вокруг центрального двухэтажного павильона расположены длинные флигели, соединенные между собой крытыми галереями. Лестница и настилка веранд мраморные. Выстлан белым мрамором также и пол громадного столового зала» [Бакунин 2007, с. 44].

Несмотря на ветхость мебели и плохое обслуживание, гостиница оказывается для российского консула воплощением современной жизни, а именно: он видит в ней характерный пример того вырождения, о котором говорилось в изданной незадолго до этого книге Макса Нордау («Вырождение», 18921893). Для Нордау современное декадентское искусство, мода, внутренняя обстановка европейских домов и многое другое свидетельствовали об утрате европейцами естественного чувства красоты. Ответственность за это возлагалась на становившийся все более интенсивным в XIX в. индустриальный труд, расстраивавший нервную систему европейцев. Бакунин прямо упоминает Нордау в связи со скверной гостиницей: европейцы, привыкшие к азиатской пище, даже наслаждающиеся ею, представляются ему извращенцами, заслуживающими внимания психиатра. Неразборчивость в еде, неспособность соблюдать приличия, несоблюдение гигиенических правил оказываются явными признаками вырождения голландцев в колонии под влиянием менее развитой местной культуры.

После Батавии путешественники направлялись в Бейтензорг (совр. Богор), который был фактическим местом пребывания генерал-губернатора Нидерландской Индии и правительственных учреждений. Ко дворцу генералгубернатора примыкал знаменитый ботанический сад. Все русские путешественники останавливались в одной и той же гостинице - «Бель вю» («Bellevue» - «Прекрасный вид» (франц.)). Самое подробное ее описание дает А.Н. Краснов, который считает ее довольно типичной для яванских гостиниц и вообще голландских домов, отличавшихся от иных европейских колониальных жилищ: «Голландская гостиница на Яве, хотя бы то и был отель 1-го ранга, мало походит на то, что мы разумеем под этим именем в Европе или других европейских колониях Азии. Она создается местными условиями жизни. Ее строй - сколок с строя жизни и устройства яванского европейского дома» [Краснов 1895, с. 279]. Как и другие путешественники, Краснов отмечает, что жара делает пребывание в комнатах крайне неприятным, в них находятся только для какой-то специальной работы, а остальное время проводят на верандах. Комнаты полутемные и небогаты мебелью, зато окружены превос- 
ходящими их по площади верандами [Краснов 1895, с. 280]. По сути, веранды это те же комнаты, туда не попадают лучи солнца и струи дождя, но их хорошо продувает ветер. Благодаря верандам создается тень для внутренних помещений. Длинное здание гостиницы «Бель вю» «прячется за еще более длинной и широкой верандой. Одноэтажная, как и все дома на Яве, она состоит из множества дверей, ведущих в маленькие полутемные комнаткиспальни, не имеющие ничего, кроме постели с пологом, умывальника, стола и нескольких стульев» [Краснов 1895, с. 280]. Таким образом, обстановка здесь оказывается примерно такой же, что и в «Отель дез Анд», где останавливался Бакунин. Краснов указывает, что общее пространство веранды разгорожено ширмами, так что образуются отдельные пространства. Перед дверью на веранде стоят стол, лонгшез и качалка, а над ними висит лампа. Неудобства гостиницы - те же, что отмечались другими путешественниками в Батавии: «Для иностранца, особенно русского, в первую минуту пребывание в подобной гостинице кажется чрезвычайно неудобным и некомфортабельным. Сидеть в комнате и темно, и душно, и тесно. Она годится лишь для спанья. Выйти на балкон - значит оказаться на виду у своих соседей, которые слышат каждое ваше движение, слово, видят все недостатки вашего утреннего костюма» [Краснов 1895, с. 280]. Краснов, однако, в отличие от Бакунина, считает возможным привыкнуть к такому образу жизни.

В гостинице существует определенный распорядок дня: в шесть часов утра «вас будит ваш лакей, малаец, внося немедленно чашку кофе. В кальсонах и какой-нибудь легкой кофточке вы выходите на веранду любоваться пробуждающимся утром» [Краснов 1895, с. 280]. В таком же виде выходят на веранды и соседи, как мужчины, так и дамы. Никто друг друга не стесняется, «ибо это не принято, а приличие - вещь условная» [Краснов 1895, с. 281]. Проведя некоторое время в безделии на веранде, жители гостиницы облачаются в тропический костюм и идут «в общую столовую съесть несколько бутербродов с ветчиной, телятиной или сыром, после чего отправляются по своим делам» [Краснов 1895, с. 281]. В час дня сервируется рисовый стол, который Краснов, как и Бакунин, описывает подробно, но без каких-либо проявлений неудовольствия; в пять часов подают чай с молоком, который пьют в таком же «беспардонном неглиже», что и утром; а в восемь вечера уже во фраках жители гостиницы выходят к обеду.

Почти 20 лет спустя, когда в гостинице остановился другой профессор ботаники, В.М. Арнольди, гостей будил около шести утра свисток первого поезда - железная дорога была проложена в непосредственной близости от гостиницы. Лишь после этого появлялись слуги-малайцы, которые разносили чай и кофе, а также будили тех, кто все еще продолжал дремать. Звуки следующего поезда, который «со свистом и грохотом проносится под террасой отеля» [Арнольди 2014, с. 69], указывали на время, когда пора закончить 
завтрак и отправиться на работу в Ботанический сад. Время в гостинице, таким образом, отмеряется звуками современной техники за окном, и быстро меняющаяся утренняя природа как будто созвучна ей: «Еще почти совершенно темно; Салак выступает в утреннем полумраке. [...] Скоро, однако, картина изменяется; быстро пролетают утренние сумерки, Салак резко выступает на чистом, ясном небе [...] и мы, проглотив чашку чая и закусывая на ходу бананом, спешим в Ботанический сад» [Арнольди 2014, с. 69]. В отличие от Краснова, отмечавшего длительные периоды безделья в гостинице, для Арнольди окружающее его пространство, наоборот, побуждает к динамичной деятельности. Обстановка комнат, однако, судя по описанию Арнольди, за эти годы существенно не изменилась. Большим неудобством, по его словам, было то, что прислуга понимала только по-малайски. При заселении удалось объясниться только с женой хозяина гостиницы, понимавшей по-французски.

Густав Радде в 1892 г. называет содержателем этой «весьма сносной» гостиницы ольденбуржца. Как и все другие путешественники, он отмечает соответствующий ее названию прекрасный вид с балкона «на речную долину, леса, луга и на вулкан Салак» [Радде 1892, с. 111]. Великий князь Сергей Михайлович даже сделал фотографию с балкона [Письма 2017, с. 101]. На завтрак великие князья отправляются к генерал-губернатору, а затем возвращаются в гостинцу, где ложатся спать до трех часов, после чего, по словам Александра Михайловича, «доктор вылез, Граббе сонный прошел, Радде шалый выполз из своего номера», Сергей Михайлович же продолжал спать «сном праведника» [Письма 2017, с. 102]. Когда все проснулись, гости пьют кофе, а на улице в это время, как обычно в Бейтензорге, идет сильный дождь. Таким образом, в гостинице гости приспосабливаются к новому для них распорядку дня, схожему с описанным Красновым.

Князь и княгиня Щербатовы, напротив, заведенному распорядку не следуют. Каждый день после утреннего чая они отправляются с визитами и осматривают достопримечательности, возвращаясь домой только вечером. В первые два вечера супруги проводят в одиночестве у себя на балконе, «по потолку и стенам которого бегали маленькие ящерицы» [Шербатова 2009, c. 114], но в последующие вечера включаются в обычную в Нидерландской Индии вечернюю светскую жизнь: им наносят визиты сначала барон Суертс де Ландас-Уиборг, генеральный секретарь Нидерландской Индии, а затем доктор Трейб, директор Ботанического сада.

Щербатовы живут более комфортно, чем Краснов и Арнольди, занимавшие небольшие комнатки: «Наши комнаты угловые выходили дверьми с одной стороны на веранду двора, а с другой - на широкий крытый балкон, служивший нам гостиной и отделенный от соседних помещений высокими ширмами. Чудный вид открывался с этого балкона, висевшего над высокой пропастью» [Щербатова 2009, с. 114]. Таким образом, по-видимому, не все 
номера были узкими и тесными, и в «Бель вю», как и в «Отель дер Недерланден», существовала социальная дифференциация постояльцев. В то же время никто из проживавших в бейтензоргской гостинице не упоминает о контактах с людьми иной социальной принадлежности, поэтому вряд ли можно согласиться с Пелегги в том, что гостиницы были местами, где пересекались и взаимодействовали представители различных социальных слоев.

В итоге свидетельства русских путешественников представляют колониальные гостиницы в целом ряде аспектов иначе, чем их описывает Пелегги. Их нельзя отнести к европейским «зонам комфорта», подобным горным поселениям в Индии. Все путешественники испытывают в гостинице в той или иной мере неудобства, хотя и относятся к ним порой с пониманием. Гостиницы отнюдь не выглядят и как форпосты современной европейской культуры. В плане гастрономии лишь одна гостиница предлагала французскую кухню, ни в одной не было заслуживающих упоминания европейских развлечений. Отношение к обстановке яванских гостиниц варьируется от возмущения до снисходительности. Правда, в то же время наблюдение за гостиничной жизнью позволяет некоторым гостям делать замечания, допускающие большую, чем принято в России, телесную свободу, рациональность одежды, отказ от некоторых приличий. Русские путешественники большей частью приспосабливались к имевшимся условиям проживания, что противоречит мнению Пелегги о том, что туристы своими требованиями активно распространяют более высокие цивилизационные стандарты.

Пелегги считает также, что гостиницы Коломбо и Сингапура укрепляли колониальную идентичность европейцев, возвращая их на время в привычное пространство европейского дома, однако в случае яванских отелей дело обстоит иначе: европейская идентичность утверждается скорее через противопоставление себя местным гостиничным условиям жизни. Особенно примечательно то, что русские путешественники не рассматривают местных голландцев в части устройства гостиниц как культурный образец, хотя одновременно они могут восхищаться голландской колониальной администрацией или Ботаническим садом и тем более - хорошо отзываться о голландцах в метрополии. В случае же яванских первоклассных гостиниц никаких западнических настроений у русских не возникает.

По-видимому, спецификой статуса путешественников и опубликованных ими текстов объясняется то, что никто из них не упоминает о каком-либо трансгрессивном опыте, связанном с сексуальностью, наркотиками или чемто еще, о чем упоминается порой в иных по характеру текстах, например в частном письме А.П. Чехова от 9 декабря 1890 г., адресованном А.С. Суворину и посвященном пребыванию в Коломбо (как указывают Д. Капустин и Р.Д. Сенасингхе, кокосовый лес, в котором происходило упоминаемое в этом письме свидание, располагался сразу за гостиницей [Капустин, Санасингхе, 
2011]). Напомним и о коротком рассказе И.А. Бунина «Сто рупий», в котором речь идет о некой гостинице с внутренним двором в старинном голландском доме рядом с кокосовым лесом, но имеется в виду, очевидно, снова Цейлон, где писатель побывал в 1911 г. Впрочем, о наличии в яванских гостиницах проституток или иных сомнительных личностей российские путешественники не упоминают и в негативном смысле, хотя в остальном не скупятся на критические отзывы.

Таким образом, яванские гостиницы, как они выглядят в рассмотренных текстах, лишь в небольшой степени соответствуют предложенной Пелегги концепции. В то же время они действительно были значимыми явлениями колониальной культуры, о чем свидетельствует наличие в той или иной мере подробных их описаний у всех приезжавших на Яву.

\section{Библиография}

Арнольди В.М. По островам Малайского архипелага: Впечатления и наблюдения натуралиста. М.: Минувшее, Архивариус, 2014. 268 с.

Бакунин М.М. Тропическая Голландия. Пять лет на острове Ява. М.: Минувшее, 2007. $429 \mathrm{c}$.

Капустин Д., Сенасингре Р.Д. Антон Чехов на Цейлоне: факты и вымыслы // Нева. 2011. № 9. С. 158-166. $443 \mathrm{c}$.

Краснов А.Н. По островам далекого Востока: путевые очерки. СПб.: Ред. «Недели», 1895.

Мирзеханов В.С. Европейцы в колониях: стиль жизни и особенности менталитета // Вестник РГГУ. Серия: Политология. История. Международные отношения. Зарубежное регионоведение. Востоковедение. 2014. № 18 (140). С. 38-53.

Письма великих князей Александра и Сергея Михайловичей друзьям «Картофельной компании», 1890-1891 / Сост. и коммент. В.Д. Лебедева. М.: Кучково поле, 2017. 255 с.

Радде Г.И. 23000 миль на яхте «Тамара». Путешествие вел. кн. Александра и Сергея Михайловичей в 1890-1891 гг. В 2 т. Т. 1. СПб.: Тип. Э. Гоппе, 1892. XXV, 228 с.

Савицкий Е.Е. Декадентская эстетика и имперские идентичности: Нидерландская Индия 1890-х глазами русского консула // Россия и современный мир. 2019. № 4. Р. 171-186.

Щербатова О.А. В стране вулканов: Путевые заметки на Яве 1893 года. М.: Минувшее, Архивариус, 2009. 254 с.

Peleggi M. The Social and Material Life of Colonial Hotels: Comfort Zones as Contact Zones in British Colombo and Singapore, ca. 1870-1930// Journal of Social History. 2012. Vol. 46. No 1. P. 124-153.

\section{References}

Arnol'di V.M. Po ostrovam Malajskogo arhipelaga: Vpechatleniya I nablyudeniya naturalista [On the Islands of the Malay Archipelago: Impressions and Observations of a Naturalist.]. Moscow: Minuvshee, Arhivarius, 2014. 268 p. (In Russ.)

Bakunin M.M. Tropicheskaja Gollandija. Pjat' let na ostrove Java [Tropical Holland. Five years on the island of Java]. Moscow: Minuvshee, 2007. 429 p. (In Russ.) 
Kapustin D., Senasingre R.D. Anton Chekhov na Cejlone: fakty I vymysly [Anton Chekhov in Ceylon: facts and fictions]. Neva. 2011. No 9. P. 158-166. (In Russ.)

Krasnov A.N. Po ostrovam dalekogo Vostoka: putevye ocherki [On the islands of the Far East: travel sketches]. Saint Petersburg: Red. «Nedeli», 1895. 443 p. (In Russ.)

Mirzekhanov V.S. Evropejcy v kolonijah: stil' zhizni i osobennosti mentaliteta [Europeans in the colonies: lifestyle and mentality]. RSUH Bulletin. Series: Political science. History. International relationships. Foreign Regional Studies. Oriental studies. 2014. No 18 (140). P. 38-53. (In Russ.)

Peleggi M. The Social and Material Life of Colonial Hotels: Comfort Zones as Contact Zones in British Colombo and Singapore, ca. 1870-1930 // Journal of Social History. 2012. Vol. 46. No 1. P. 124-153.

Pis'ma velikih knyazej Aleksandra i Sergeya Mihajlovichej druz'yam «Kartofel'noj kompanii», 1890-1891 [Letters of the Grand Dukes Alexander and Sergei Mikhailovich to the friends of the Potato Company, 1890-1891]. Ed. by V.D. Lebedev. Moscow: Kuchkovo pole, 2017. 255 p. (In Russ.)

Radde G.I. 23000 mil' na yahte «Tamara». Puteshestvie vel. kn. Aleksandra i Sergeya Mihajlovichej v 1890-1891 gg. [23,000 miles on the yacht «Tamara». Travel of the Grand Dukes Alexander and Sergei Mikhailovich in 1890-1891]. 2 vols. Vol. 1. Saint Petersburg: Tip. E. Goppe, 1892. XXV, 228 p. (In Russ.)

Savitskiy E.E. Dekadentskaya estetika i imperskie identchnosti: Niderlandskaya Indiya 1890-h glazami russkogo konsula [Decadent aesthetics and imperial identities: Netherlands Indies of the $1890 \mathrm{~s}$ as seen by the Russian consul]. Russia and the contemporary world. 2020. No 4. P. 171-186. (In Russ.)

Shcherbatova O.A. V strane vulkanov: Putevye zametki na Yave 1893 goda [In the Land of Volcanoes: Travel Notes in Java 1893]. Moscow: Minuvshee, Arhivarius, 2009. 254 p. (In Russ.) 